\title{
Audyt przestrzeni publicznych, jako narzędzie monitorowania i kreowania przestrzeni atrakcyjnych dla rozwoju kapitału ludzkiego
}

\section{Wstęp - kreatywność a innowacyjność}

Innowacyjność rozumiana jest często jako skłonność do ustawicznego poszukiwania i wykorzystywania w praktyce wyników badań naukowych, nowych koncepcji i pomysłów. Cecha ta jest właściwa jednostkom, które są odpowiednio zmotywowane i potrafia, wykorzystując proinnowacyjne zasoby (ludzkie, rzeczowe, finansowe, informacyjne), tworzyć nowe wartości i nową jakość w rozumieniu materialnym, organizacyjnym i społecznym ${ }^{1}$.

Innowacyjność często jest także utożsamiana $\mathrm{z}$ pojęciem kreatywności. W tym przypadku jednak, mimo silnego związku między nimi, należy zwrócić uwagę na różnice, których zrozumienie pozwala skuteczniej oddziaływać na efekt finalny - budowanie zdolności innowacyjnych. Kreatywność jest procesem myślenia, w wyniku którego generowane są pomysły. Jest to proces trudny do pomiaru i oceny, a nawet niemierzalny ${ }^{2}$. Innowacyjność jest natomiast procesem skoncentrowanym na wyborze i implementacji nowych pomysłów w procesy gospodarcze. Kreatywność można utożsamiać z procesem produkowania idei, podczas gdy innowacyjność oznaczać będzie zdolność do realizacji procesów ich implementacji ${ }^{3}$. Kreatywność określa twórcze zdolności umysłu, determinujące powstawanie nowych idei i koncepcji, prowadzące do uzyskania oryginal-

\footnotetext{
* Adiunkt, Katedra Gospodarki Regionalnej i Środowiska, Wydział Ekonomiczno-Socjologiczny, Uniwersytet Łódzki. E-mail: zbycho@uni.lodz.pl

1 A. Nowakowska, Regionalny wymiar procesów innowacji, Wydawnictwo Uniwersytetu Łódzkiego, Łódź 2011, s. 40.

${ }^{2}$ K. Petrikova, A. Vanova, K. Borsekova, The role of creative economy in Slovak Republic, Springer-Verlag London 2013, AI \& Soc DOI 10.1007/s00146-013-0508-5

${ }^{3}$ Ch. Landry, F. Bianchini, The creative city, Demos Paper, no. 12, 1995, s. 20.
} 
nych rozwiązań. Cecha ta określa osobę wykazującą się szeroką wyobraźnią oraz artystyczną lub intelektualną pomysłowością. Upraszczając można zatem powiedzieć, że kreatywność jest procesem, w którym powstają nowe pomysły, a innowacyjność procesem ich wdrażania. Kreatywność jest niezbędnym warunkiem do zaistnienia innowacyjności, ale to dopiero innowacyjność jest właściwością maksymalizującą potencjał ludzki miast i regionów ${ }^{4}$. W tej perspektywie zarówno kreatywność, jak i innowacyjność mają swoją wartość ekonomiczną ${ }^{5}$.

Kreatywność jest cechą dotyczącą każdego człowieka, za pomocą której można określić poziom ,zdolności tworzenia nowych rzeczy, nowych sposobów rozwiązywania problemów" ". Nie oznacza to jednak, że każdy człowiek jest kreatywny, choć cechę tę można kształtować inwestując w elementy pobudzające, stymulujące, czy wręcz prowokujące ową kreatywność.

\section{Właściwości przestrzeni jako determinanty aktywności ka- pitału ludzkiego}

Wiedza to jedyny czynnik produkcji, którego zasoby powiększają się wraz z poziomem wykorzystywania ${ }^{7}$. Tym samym, prowokując kapitał ludzki do koncentracji w przestrzeni można oddziaływać na zwiększenie jego produktywności i efektywności wykorzystania. Analogicznie do procesów koncentracji działalności gospodarczej czy kapitału finansowego w gospodarce kapitalistycznej XIX i XX w., podobne właściwości wykazują dziś nowe czynniki rozwoju. Kapitał kreatywny ma tendencję do naturalnej koncentracji w przestrzeni. Dochodzi do powstawania klastrów kapitału ludzkiego i zdaniem niektórych badaczy jest to zjawisko ważniejsze niż clustering przedsiębiorstw ${ }^{8}$. Kapitał kreatywny koncentruje się w naturalny sposób w miastach i od warunków, jakie są tam obecne zależy natężenie tej koncentracji, a w konsekwencji konkurencyjność samych miast. Można wręcz mówić o rozwoju miast kreatywnych lub rozwoju miast

\footnotetext{
${ }^{4}$ Creative Economy Report 2010, s. 13.

${ }^{5}$ D. Throsby, Ekonomia i kultura, Narodowe Centrum Kultury, 2010, s. 89-100.

${ }^{6}$ F. Kuźnik, Modele kreatywnej aglomeracji miejskiej [w:] Kreatywna aglomeracja - potencjaty, mechanizmy, aktywności. Podejścia metodologiczne, A. Klasik (red.), Prace Naukowe Akademii Ekonomicznej im. K. Adamieckiego w Katowicach, Wydawnictwo Akademii Ekonomicznej w Katowicach, Katowice 2008, s. 13.

${ }^{7}$ V. K. Matur, Human capital-based strategy for regional economic development, Economic Development Quarterly 1999, s. 203; A. Nowakowska, Z. Przygodzki, M. Sokołowicz, Region $w$ gospodarce opartej na wiedzy. Kapitat ludzki, innowacje, korporacje transnarodowe, Wydawnictwo Difin, Warszawa 2011, s. 13.

${ }^{8}$ R.E. Lucas, On the Mechanics of Economic Development, Journal of Monetary Economics, 1988, no. 22, s. 38; R. Florida, The Rise of the Creative Class. And How It's Transforming Work, Leisure, Community and Everyday Life, Basic Books, New York 2002, p. 221.
} 
w oparciu o sektor kreatywny ${ }^{9}$. Ważnym elementem miasta kreatywnego jest rozbudowany i prężnie działający sektor kreatywny, stanowiący trzon gospodarki oraz motor napędzający rozwój miast ${ }^{10}$. Istnienie i prawidłowe funkcjonowanie sektora kreatywnego, wymaga specyficznego otoczenia, w postaci środowiska kreatywności (creative milieu $^{l 1}$ ) i kreatywnej atmosfery ${ }^{12}$. Według koncepcji A. Anderssona kreatywne środowisko konstytuuje się dzięki koncentracji w przestrzeni takich czynników jak: stabilna i mało rozdrobniona baza finansowa; kompetencje i unikalna wiedza; różnorodność środowiska miejskiego; dobrze zorganizowana komunikacja zewnętrzna i wewnętrzna, telekomunikacja; głęboka niepewność co do przyszłości w środowiskach naukowych i technicznych $^{13}$. Listę tę uzupełnia także R. Florida wskazując, iż główne czynniki kreatywności miasta powinny tworzyć intelektualny ekosystem, który składa się $\mathrm{z}^{14}$ :

- rozbudowanej infrastruktury kulturalnej;

- dojrzałego środowiska społecznego;

- zróżnicowanych możliwości dla spędzania czasu wolnego;

- odpowiednich warunków stwarzanych w miejscu pracy.

W kontekście niniejszego artykułu warto zwrócić szczególną uwagę na te spośród wymienionych czynników, które jak określa Florida, determinują otwartość i różnorodność miejsc, stwarzając realne szanse na podniesienie poziomu rozwoju gospodarczego, dzięki zdolności do przyciągania i zatrzymywania ludzi

${ }^{9}$ Z. Przygodzki, Kreatywność i zdolności innowacyjne kapitalu ludzkiego, w kontekście warunków kształtowania jakości otoczenia lokalnego [w:] Oblicza innowacyjności w regionie, M. E. Sokołowicz, E. Kina (red.), Acta Universitatis Lodziensis Folia Oeconomica, 290, Łódź 2013.

${ }^{10}$ A. Klasik, Od sektora kultury do przemystów kreatywnych [w:] Od przemystów kultury do kreatywnej gospodarki, A. Gwóźdź (red.), Warszawa 2010, Narodowe Centrum Kultury, s. 47-63; A. Drobniak, Kultura i przemysty kreatywne - doświadczenia, tendencje rozwoju, nowe obszary badawcze w miastach [w:] Kreatywna gospodarka w mieście i aglomeracji, A. Klasik, (red.), Wydawnictwo Uniwersytetu Ekonomicznego w Katowicach, Katowice 2012, s. 21-40.

11 Pojęcie środowiska kreatywnego (ang. creative milieu) wprowadził Gunnar Törnqvist w 1978 roku, w swoim eseju pt. „Creativity and the renewal of regional life”. Środowisko to nazywane jest także środowiskiem twórczym. Obszary zaliczane do środowiska kreatywnego według autora cechują się występowaniem trzech rodzajów zasobów: informacji i łatwości jej przenoszenia w obszarze jednostki; wiedzy i zdolności do jej akumulacji w czasie; kompetencji w określonych rodzajach działalności. Jednoczesne występowanie wymienionych zasobów i zdolności na określonym obszarze doprowadza do rozwoju czwartego zasobu, jakim jest kreatywność. Jest ona pojmowana jako zdolność twórcza, doprowadzająca do powstawania nowych form i wartości, zarówno tych materialnych, jak i niematerialnych. G. Törnqvist, Creativity and the renewal of regional life [w:] A. Buttimer (red.) Creativity and Context, Lund Studies in Geography. Series B. Human Geography, 1983, no. 50.

${ }^{12}$ W. Santagata, E. Bertacchini, Creative atmosphere: cultural industries and local development, International Centre for Research on the Economics of Culture, Institutions, and Creativity (EBLA), Working paper 2011, no. 4, s. 3-4.

${ }^{13}$ P. Hall, Creative Cities and Economic Development, Urban Studies, Vol. 37, no. 4, 2000, s. 664-645.

${ }^{14}$ R. Florida, The Flight of the Creative Class, Harper Business, New York 2004, s. 39. 
o wysokim potencjale twórczym ${ }^{15}$. Niewątpliwie, do tego typu właściwości należy zaliczyć m.in. jakość przestrzeni publicznych, jak i otoczenia miejsca pracy. Ch. Landry i F. Bianchini potwierdzają ten punkt widzenia i wśród czynników determinujących kreatywność członków społeczności lokalnej wymieniają między innymi stan przestrzeni miejskich, udogodnienia i atrakcyjność oraz istnienie tożsamości lokalnej ${ }^{16}$. Tak zwana „trzecia przestrzeń miejska” to miejsca posiadające właściwości stymulacyjne dla społeczności miejskiej w obszarze komunikacji społecznej, budowania relacji, pobudzania kreatywności ${ }^{17}$. Istotność tych elementów można dostrzec także w proponowanym przez A. Klasika modelu ogólnym miasta kreatywnego ${ }^{18}$. Model ten opiera się o współdziałanie i interakcje pomiędzy czterema komponentami: przestrzenią, ludźmi, infrastrukturą i różnymi aktywnościami. Przestrzeń miasta kreatywnego powinna tworzyć jak najbardziej atrakcyjne warunki do rozwoju twórczości oraz nowoczesnych technologii i innowacji. Podstawą atrakcyjności miejsca jest wysoka jakość życia, którą kreuje w sferach społecznych, kulturowych i środowiskowych ${ }^{19}$. Jak

${ }^{15}$ R. Florida, The Flight of the Creative Class, Harper Business, New York 2004, s. 3.

${ }^{16}$ Autorzy wskazują ponadto także inne czynniki determinujące kreatywność mieszkańców miasta: cechy personalne mieszkańców (utalentowanie), zdolność do tworzenia i kreowania; silne przywództwo miejskie i chęć do zmian; zróżnicowane społeczeństwo - dostęp do różnorodnych talentów; istnienie i jakość kultury organizacyjnej miasta; istnienie odpowiedniej dynamiki sieciowej (zdolności do sieciowania) Ch. Landry, F. Bianchini, The creative city, Demos Paper 1995, no. 12 , s. $25-31$.

${ }^{17}$ A. Drobniak, Kultura i przemysty kreatywne - doświadczenia, tendencje rozwoju, nowe obszary badawcze w miastach [w:] Kreatywna gospodarka w mieście i aglomeracji, A. Klasik (red.), Wydawnictwo Uniwersytetu Ekonomicznego w Katowicach, Katowice 2012, s. 25.

${ }^{18}$ A. Klasik, Kreatywne i atrakcyjne miasta. Koncepcje i mechanizmy restrukturyzacji aglomeracji miejskich [w:] Kreatywna aglomeracja - potencjaty, mechanizmy, aktywności. Podejścia metodologiczne, A. Klasik (red.), Prace Naukowe Akademii Ekonomicznej im. K. Adamieckiego w Katowicach, Wydawnictwo Akademii Ekonomicznej w Katowicach, Katowice 2008, s. 50-52.

${ }^{19}$ Autor wyjaśnia dalej, iż miasto kreatywne, poprzez swoje wewnętrzne uwarunkowania oraz odpowiednią politykę urbanistyczną, jest w stanie generować przyciaganie. W efekcie, na jego teren zaczynają napływać nowe inwestycje, wysoko ceniony kapitał społeczny i klasa kreatywna generująca twórcze idee i pomysły, które jeszcze bardziej napędzają rozwój. Podsumowując, stwierdzić można, iż miasto kreatywne odznacza się dodatnim saldem urbanizującym, przepływów idei, ludzi i inwestycji. Drugim komponentem kreatywnej jednostki są ludzie, a w głównej mierze ich talenty i pasje, które prowadzą do wzmacniania wewnętrznych sił witalnych miasta. Dzięki dużej koncentracji klasy kreatywnej powstają tzw. „kreatywne środowiska”, które są swego rodzaju regionami twórczości, miejscami, gdzie skupia się działalność sektora kreatywnego. Im większy udział klasy kreatywnej wśród społeczeństwa miejskiego, tym szybciej rozprzestrzenia się praktyka twórczego myślenia wśród lokalnej zbiorowości. Kreatywność zaczyna się rozprzestrzeniać zarówno w sferze sektora prywatnego, jak również w instytucjach sektora publicznego, biznesowego i społecznego, tym samym staje się źródłem wprowadzania nowych praktyk, eksperymentowania oraz inicjowania unikatowych wartości. Społeczeństwo staje się bardziej odważne, nie boi się swoich pomysłów i zaczyna wdrażać coraz bardziej kreatywne rozwiązania. Dużą rolę w tworzeniu kreatywnego środowiska ma również przedsiębiorczość społeczności lokalnej oraz władz jednostki. Miasta dysponujące nowym rodzajem kapitału ludzkiego, który odznacza się wysokim wykształceniem i kompetencjami zawodowymi, posiada zdolność adaptacji do zachodzących 
pisze A. Lisowski ,„przestrzeń to nieograniczony pojemnik wielkości i różnorodności, a zarazem instrumentalna koncepcja integracji różnych kategorii zjawisk i procesów" ${ }^{20}$. Podstawowym kryterium jej zagospodarowania w miastach powinien być ład przestrzenny. Kryterium to jest ważniejsze nawet od organizacji przestrzennej, ustalającej porządek funkcji służących celom społecznym, ponieważ oddziałuje na istotne wartości społeczne, dotyczące przede wszystkim właśnie maksymalizacji jakości życia, minimalizacji konfliktów funkcjonalnoprzestrzennych oraz harmonijnie ukształtowanego krajobrazu ${ }^{21}$. Drugim ważnym elementem w budowaniu atrakcyjności miasta jest również stan jego infrastruktury technicznej oraz społecznej. Przy czym nie chodzi jedynie o jej dostępność czy mobilność, natomiast ważne jest aby pełniła ona funkcje integrujące względem społeczności lokalnej, środowisk biznesowych, środowiska kreatywnego, instytucji i jednostek naukowo-badawczych.

Elementy te uważane są za podstawowe nośniki atrakcyjności i/lub kreatywności danego miejsca, a także decydują o tym, że badane miasto jest kreatywne lub ma podstawy do stworzenia kreatywnego i atrakcyjnego środowiska. Proces dostosowywania $i$ adaptowania przestrzeni miejskiej oraz jej komponentów do warunków gospodarki opartej na wiedzy, przybiera postać specyficznej restrukturyzacji aglomeracji ${ }^{22}$. Należy pamiętać, iż przestrzeń publiczna jest jednym z produktów miasta, który wykorzystywany jest w procesie konkurowania. Miasta konkurują między sobą, co oznacza, że istnieje rynek, na którym, jak pisze P. Lorens ,„przedkładana jest oferta specyficznych produktów miasta, spośród której wybierają zarówno inwestorzy, potencjalni mieszkańcy, jak i turyści. (...) Zróżnicowanie wewnętrzne miast wiąże się więc z oceną przestrzeni miejskiej, a raczej jej poszczególnych fragmentów. Dzięki tej ocenie konsumenci mogą świadomie wybrać określone produkty miejskie. Wybór ten warunkowany

w otoczeniu zmian. (A. Klasik, Kreatywne i atrakcyjne miasta. Koncepcje i mechanizmy restrukturyzacji aglomeracji miejskich [w:] Kreatywna aglomeracja - potencjały, mechanizmy, aktywności. Podejścia metodologiczne, A. Klasik (red.), Prace Naukowe Akademii Ekonomicznej im. K. Adamieckiego w Katowicach, Wydawnictwo Akademii Ekonomicznej w Katowicach, Katowice 2008, s. 51.

${ }^{20}$ A. Lisowski, ,Przestrzeń” $i$,percepcja” $w$ trans dyscyplinarnych badaniach miast - spojrzenie geografa. [w:] M. Madurowicz (red.) Percepcja współczesnej przestrzeni miejskiej, Uniwersytet Warszawski, Wydział Geografii i Studiów Regionalnych, Instytut Geografii SpołecznoEkonomicznej i Gospodarki Przestrzennej, Warszawa 2007, s. 22.

${ }^{21}$ A. Lisowski, ,Przestrzen” $i$, ,percepcja” $w$ transdyscyplinarnych badaniach miast - spojrzenie geografa [w:] Percepcja współczesnej przestrzeni miejskiej, M. Madurowicz (red.), Uniwersytet Warszawski, Wydział Geografii i Studiów Regionalnych, Instytut Geografii SpołecznoEkonomicznej i Gospodarki Przestrzennej, Warszawa 2007, s. 21.

${ }^{22}$ A. Klasik, Kreatywne $i$ atrakcyjne miasta. Koncepcje i mechanizmy restrukturyzacji aglomeracji miejskich. [w:] Kreatywna aglomeracja - potencjaty, mechanizmy, aktywności. Podejścia metodologiczne, A. Klasik (red.), Prace Naukowe Akademii Ekonomicznej im. K. Adamieckiego w Katowicach, , Wydawnictwo Akademii Ekonomicznej w Katowicach, Katowice 2008, s. 51. 
jest dążeniem do unikania doświadczeń nieprzyjemnych (...) oraz chęcią konsumpcji atrakcyjnych doświadczeń kulturowych"23.

Jakość otoczenia, stanowiącego miejsce życia i pracy człowieka, pozostaje także jednym z kluczowych priorytetów nowej urbanistyki, której cechy identyfikowane są m.in. w Karcie Lipskiej ${ }^{24}$, czy w ujęciu pragmatycznym, poprzez realizowane $\mathrm{w}$ różnych częściach świata projekty new century cities. Kształtowane w tym duchu nowe, lub przywracane miastu ,stare" przestrzenie, są wyrazem poszukiwania nowego sposobu funkcjonowania miast, zdolnych do wykorzystywania $\mathrm{w}$ procesie konkurencji zasobów intelektualnych oraz nowoczesnych osiągnięć nauki i techniki, szczególnie w dziedzinie technologii $\mathrm{ICT}^{25}$. Jednym z ważniejszych celów operacyjnych tych działań, jest natomiast zaproponowanie mieszkańcom sposobu życia, zorientowanego na interakcje i kreatywność, możliwość „uprawiania” różnorodnych stylów życia oraz „celebrację doświadczania miejsca i więzi społecznych"26. Mówi się wręcz o tzw. nowej praktyce projektowania miast (ang. new practice of urban design), której celem jest zaproponowanie komunikatywnych przestrzeni publicznych, nie mających jedynie właściwości funkcjonalnych, ale przekazujących użytkownikowi informacje historyczne, wiedzę związaną z dziedzictwem kulturowym i inne treści. Takie właściwości miejsca determinowane są cechami gospodarki informacyjnej. D. Frenchman nazywa tego typu przestrzenie miejscami narracyjnymi (ang.

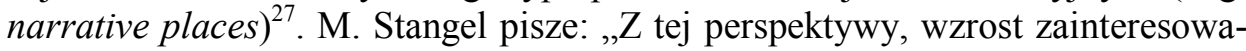
nia dziedzictwem kulturowym nie jest powodowany nostalgią za przeszłością, jak chcą niektórzy krytycy, ale wymagany jest przez siły, które tworzą przyszłość. (...) Oczekiwania co do informacji w środowisku miejskim związane są z kulturą mediów, poszukiwaniem nowych doświadczeń i wrażeń, jak również $\mathrm{z}$ faktem, że ludzie poruszają się obecnie w miejscach nowych i nieznanych

${ }^{23} \mathrm{P}$. Lorens, Wspótczesne tendencje rozwoju struktur miejskich. Znaczenie procesów przeksztatceń i rewitalizacji [w:] Miasto, metropolia, region. Wybrane zagadnienia rewitalizacji miast, P. Lorens i J. Martyniuk-Pęczek (red.), Wydawnictwo Urbanista, Gdańsk 2009, s. 15.

${ }^{24}$ Karta Lipska na rzecz zrównoważonego rozwoju miast europejskich, przyjęta z okazji nieformalnego spotkania ministrów w sprawie rozwoju miast i spójności terytorialnej w Lipsku, w dniach 24-25 maja 2007 r. CdR 163/2007 EN - AW(ASZ)/ak.

${ }^{25} \mathrm{M}$. Stangel, Możliwości technologii informacyjnych $i$ komunikacyjnych (ICT) $w$ procesach rewitalizacji [w:] Miasto, metropolia, region. Wybrane zagadnienia rewitalizacji miast, P. Lorens, J. Martyniuk-Pęczek (red.), Wydawnictwo Urbanista, Gdańsk 2009, s. 150-151.

${ }^{26}$ New Century City Developments creating extraordinary value, Third Global Workshop. November 9-11, Seoul, Korea 2009, s. 9. Szerzej także: J. Gehl, Życie między budynkami. Użytkowanie przestrzeni publicznych, Wydawnictwo RAM, Kraków 2009; Ch. Alexander, Język Wzorców. Miasta, budynki, konstrukcja, Gdańskie Wydawnictwo Psychologiczne, Sopot 2008.

27 P.J. Latimer-Knowles, Communicative place-making: participatory planning and the enhancement of sense, The 4th International Conference of the International Forum on Urbanism (IFoU) Amsterdam 2009 /Delft The New Urban Question - Urbanism beyond Neo-Liberalism 2009. 
w wiele większym stopniu, niż kiedykolwiek wcześniej”28. P. Śpiewak podkreśla, „iż „dawność” pozostaje w budynkach, pomnikach przeszłości, kształtujących naszą wrażliwość i wyobraźnię"29.

\section{Konstrukcja karty audytu przestrzeni publicznych}

Miejsce i jego właściwości mają duże znaczenie w kształtowaniu kapitału kreatywnego miasta. Potwierdza to między innymi fakt, iż badacze tego problemu Ch. Landry i J. Hyams konstruując Creative City Index, jako narzędzie diagnostyczne o właściwościach benchmarkingu, dwa spośród dziesięciu obszarów identyfikacji zarezerwowali właśnie na tę przestrzeń analizy. Obszary te dotyczą identyfikacji właściwości miejsca (ang. the place \&placemaking) oraz jakości życia z tym związanej (ang. liveability\& well-being) ${ }^{30}$. Stąd prowadząc badania nad lokalnymi i regionalnymi uwarunkowaniami rozwoju kapitału ludzkiego, zdecydowano również uwzględnić ten obszar analizy. W tym przypadku nie podjęto jednak badań pierwotnych, a opierając się na wnioskach wskazywanych w literaturze przedmiotu przyjęto a priori założenia, o wpływie otoczenia na zdolności twórcze i aktywność człowieka. Podjęte badania mają natomiast wymiar głównie aplikacyjny. Celem artykułu było opracowanie narzędzia, które mogłyby zostać wykorzystane do systemowego diagnozowania i oceny atrakcyjności przestrzeni publicznych, z punktu widzenia jej walorów determinujących aktywność i kreatywność kapitału ludzkiego. W wyniku działań, opracowano metodykę realizacji audytu przestrzeni publicznych oraz przygotowano narzędzie w postaci aplikacji komputerowej, do realizacji standardowej i łatwo powtarzalnej procedury jego wykonywania. Narzędzie to pozwala w prosty i systemowy sposób monitorować i naprawiać przestrzenie publiczne, pod kątem ich właściwości inspirujących do działania i pobudzających pomysłowość ludzi. Narzędzie zorientowane jest na monitoring w zakresie przestrzeni, które ze względu na swoje dominujące funkcje, stanowią często otoczenie pracy, miejsce spędzania czasu wolnego i życia ludzi odpowiedzialnych w zdecydowanej większości za tworzenie zasobów wiedzy innowacyjnej i zaawansowanej ${ }^{31} \mathrm{~W}$ miastach.

${ }^{28}$ M. Stangel, Możliwości technologii informacyjnych i komunikacyjnych (ICT) $w$ procesach rewitalizacji [w:] Miasto, metropolia, region. Wybrane zagadnienia rewitalizacji miast, P. Lorens, J. Martyniuk-Pęczek (red.), Wydawnictwo Urbanista, Gdańsk 2009, s. 144.

${ }_{29}$ P. Lorens, Definiowanie współczesnej przestrzeni publicznej [w:] Miasto, metropolia, region. Wybrane zagadnienia rewitalizacji miast, P. Lorens, J. Martyniuk-Pęczek (red.), Wydawnictwo Urbanista, Gdańsk 2009, s. 11.

30 Creative City Index, 2013. Dostępny w: http://www.creativecityindex.org/ (Dostęp: 20.03.2013).

${ }^{31}$ A. Nowakowska, Z. Przygodzki, M. Sokołowicz, Region w gospodarce opartej na wiedzy. Kapitat ludzki, innowacje, korporacje transnarodowe, Wydawnictwo Difin, Warszawa 2011, s. 18-19. 
Konstrukcja karty audytu przestrzeni publicznych została oparta na kanwie rozumowania zawartego w książce pt. Jak przetworzyć miejsce. Podręcznik kreowania udanych przestrzeni publicznych ${ }^{32}$, gdzie w odpowiedzi na pytanie: co czyni miejsce znakomitym? - wskazano cztery płaszczyzny obserwacji. Stąd kartę audytu przestrzeni publicznych podzielono także na cztery obszary analizy: wartość społeczna, komfort i wizerunek, dostępność oraz funkcje i działania.

Rysunek 1. Informacje ogólne i struktura karty audytu przestrzeni publicznych (strona pierwsza aplikacji komputerowej)

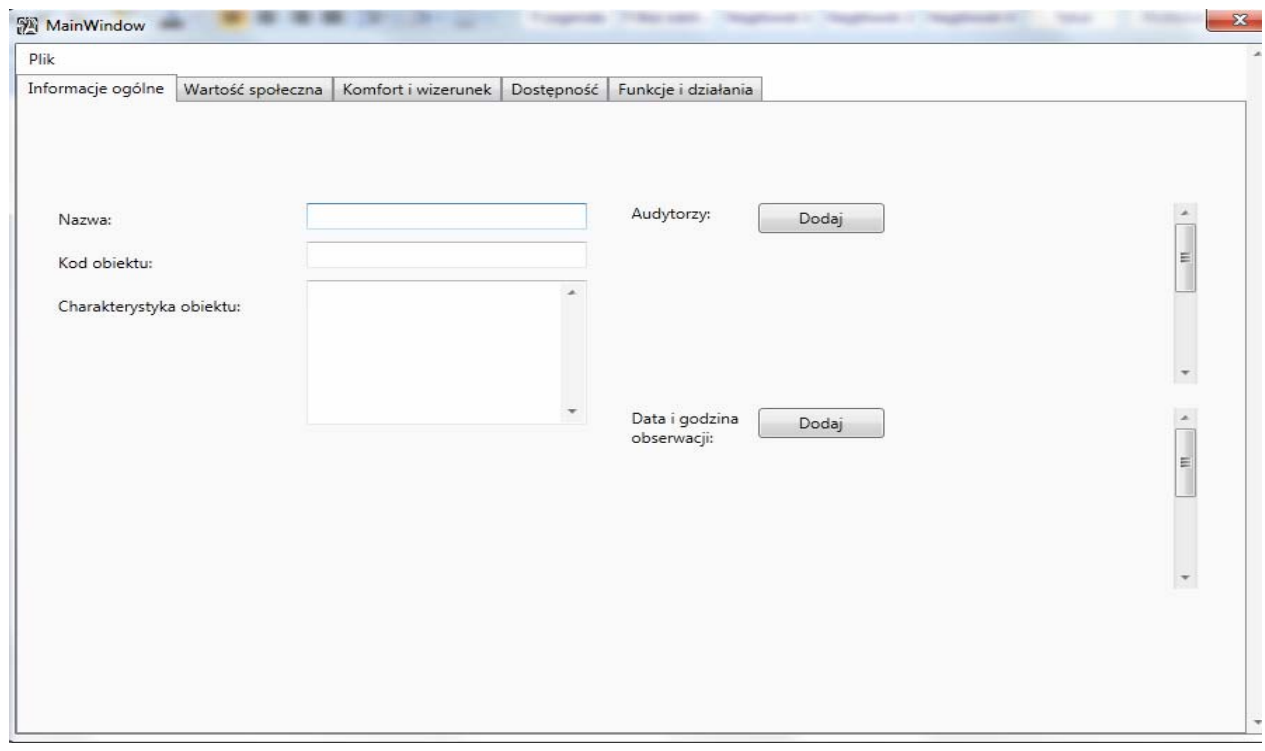

W oparciu o studia literaturowe, odwołując się między innymi do prac Ch. Aleksandra ${ }^{33}$, J. Gehla ${ }^{34}$, W. Wiśniewskiej ${ }^{35}$, J. H. Crowforda ${ }^{36}$ ustalono zbiory miar. Dla każdego z obszarów przyjęto wskaźniki, które jako stymulanty lub destymulanty diagnozują monitorowaną przestrzeń. Przyjęte wskaźniki ilu-

${ }^{32}$ Jak przetworzyć miejsce. Podręcznik kreowania udanych przestrzeni publicznych, Fundacja Partnerstwo dla Środowiska, Kraków 2009.

${ }^{33} \mathrm{Ch}$. Alexander, Język Wzorców. Miasta, budynki, konstrukcja, Gdańskie Wydawnictwo Psychologiczne, Sopot 2008.

${ }^{34}$ J. Gehl, Życie między budynkami. Użytkowanie przestrzeni publicznych, Wydawnictwo RAM, Kraków 2009.

${ }^{35}$ W. Wiśniewska, Krajobraz miejski: odnowa i kreacja w procesie odnowy, Wydawnictwo Politechniki Łódzkiej, Łódź 2012.

${ }^{36}$ J. H. Crawford, Carfree Cities, Ulrecht International Books 2002; J. H. Crawford, Carfree design manual, Ulrecht International Books 2009. 
strują natężenie zjawiska w skali siedmiopunktowej. Zastosowano także miary, które mogą przyjmować wartości neutralne, pozytywne lub negatywne - w tym przypadku na skali znajduje się wartość zero i ocena trzypunktowa in plus oraz taka sama in minus. Wartości poszczególnych wskaźników w ramach obszaru są sumowane ilustrując syntetycznie ocenę. Jest to szczególnie istotne z punktu widzenia:

- powtarzalności wykorzystywania narzędzia;

- łatwości dokonywania oceny;

- weryfikacji kierunku dokonywanych zmian w czasie.

Rysunek 2. Wizualizacja obszarów analizy i zapisu wskaźników w karcie audytu przestrzeni publicznych (fragmenty kolejnych zakładek aplikacji)

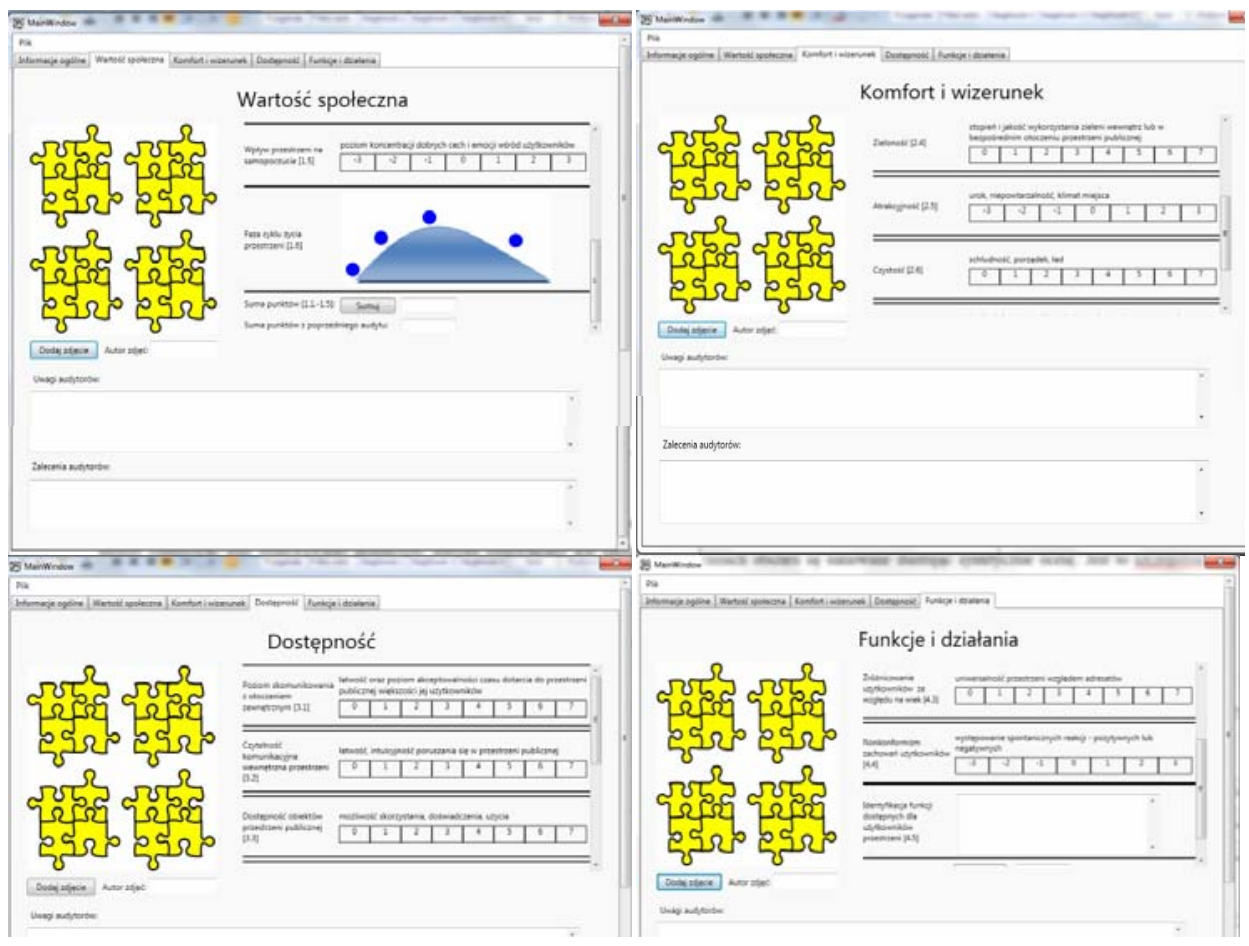

Obok oceny punktowej, która ma w syntetyczny, ale także stosunkowo obiektywny i czytelny sposób zilustrować stan obserwowanej przestrzeni, audytor zobowiązany jest zamieścić w karcie audytu dokumentację fotograficzną dla każdego z obszarów analizy, każdorazowo w postaci czterech fotografii, obrazujących stan przestrzeni i potwierdzających występowanie (natężenie) zjawisk, 
określonych za pomocą wskaźników punktowych. Jest to istotne również z uwagi na fakt, że audyt może być realizowany przez różnych audytorów, szczególnie w kolejnych okresach, natomiast dokumentacja w takiej postaci pozwala:

- w łatwy sposób skalibrować punkty odniesienia, osobie pełniącej funkcję audytora podczas kolejnej edycji audytu;

- zrozumieć i podjąć właściwe działania, przez podmioty odpowiedzialne za wprowadzenie zaleceń, wskazanych przez audytora w karcie audytu.

Każdy z obszarów analizy zawiera miejsce na sformułowanie w syntetyczny i czytelny sposób zaleceń audytora realizującego badanie. Zalecenia te, w zależności od sposobu wdrożenia narzędzia (w trybie fakultatywnym lub obligatoryjnym) mogą lub powinny być wprowadzone. Ponadto każdy z obszarów analizy zawiera pole na ewentualne uwagi audytora, które w specyficzny sposób, zazwyczaj krótkookresowo uniemożliwiają lub zniekształcają właściwą percepcję obserwowanej przestrzeni (np. podczas remontu, przebudowy, braku lub ograniczonej dostępności w czasie prowadzenia audytu).

Audyt w zdefiniowanej formule testowano trzykrotnie na wybranych przestrzeniach publicznych Łodzi. Cel badania i właściwości przygotowanego narzędzia zdeterminowały wybór katalogu przestrzeni wskazanych do badania wytypowano dwie grupy przestrzeni publicznych otwartych: o przeważających funkcjach miejsc centralnych (1) i przestrzeni użytkowanych, przede wszystkim przez naukowców, badaczy, wynalazców i szerzej - środowiska akademickie w Łodzi (2). W kolejnych trzech latach analizy (2011-2013) przygotowano po 67 ważnych kart audytu. Obok tego, audyt testowany był na większej liczbie przestrzeni publicznych, w tym w pierwszej edycji zrealizowano go w przestrzeniach publicznych zamkniętych i testowano w przestrzeniach publicznych otwartych, o dominującej funkcji transportowej, jednak stwierdzono, że narządzie w zaproponowanym kształcie nie jest dobrze przystosowane do monitorowania tego typu miejsc.

Przygotowane narzędzie - Kartę audytu przestrzeni publicznych - w postaci aplikacji komputerowej wraz z instrukcją użytkowania można pobrać ze strony internetowej pod adresem: www.region.uni.lodz.pl/Zbigniew_Przygodzki. Wydruk komputerowy, finalną formę przykładowego zrealizowanego audytu zamieszczono w załączniku nr 1 .

\section{Podsumowanie}

Miasta oddziałując na jakość życia mieszkańców reorganizują przestrzenie publiczne. W większości przypadków trudno jednak mówić o prawdziwym procesie zarządzania w tej sferze nie tylko z uwagi na brak lub nieciagłość planowania, ale także na, niemal powszechny, brak systemów monitorowania zmian 
i identyfikowania potrzeb. Wbrew pozorom interwencje w zakresie poprawy jakości przestrzeni publicznych nie są działaniami ograniczającymi się do poprawy estetyki czy inwestycji infrastrukturalnych, których celem jest remont, renowacja czy odbudowa. Przestrzenie publiczne zgodnie ze swoimi funkcjami powinny służyć ludziom. $Z$ tej perspektywy niezbędne jest identyfikowanie potrzeb, wprowadzanie zmian, kontrola efektów oraz bieżąca korekta w zakresie ich jakości. Podstawą skuteczności działań w tym przypadku jest niewątpliwie zapewnienie systematyczności i ciągłości systemu ich monitorowania i oceny.

\section{Bibliografia}

Alexander Ch., Język Wzorców. Miasta, budynki, konstrukcja, Gdańskie Wydawnictwo Psychologiczne, Sopot 2008.

Creative City Index, 2013. http://www.creativecityindex.org/ (Dostęp: 20.03.2013).

Creative Economy Report 2010

Crawford J. H., Carfree Cities, Ulrecht International Books 2002.

Crawford J. H., Carfree design manual, Ulrecht International Books 2009.

Drobniak A., Kultura i przemysly kreatywne - doświadczenia, tendencje rozwoju, nowe obszary badawcze w miastach [w:] Kreatywna Gospodarka w mieście i aglomeracji, Klasik A. (red.), Wydawnictwo Uniwersytetu Ekonomicznego w Katowicach, Katowice 2012.

Florida R., The Flight of the Creative Class, New York: Harper Business, 2004.

Florida R., The Rise of the Creative Class. And How It's Transforming Work, Leisure, Community and Everyday Life, Basic Books, New York 2002.

Gehl J., Życie między budynkami. Użytkowanie przestrzeni publicznych, Wydawnictwo RAM, Kraków 2009.

Hall P., Creative Cities and Economic Development. Urban Studies. Vol. 37, no. 4, 2000.

Jak przetworzyć miejsce. Podręcznik kreowania udanych przestrzeni publicznych, Fundacja Partnerstwo dla Środowiska, Kraków 2009.

Karta Lipska na rzecz zrównoważonego rozwoju miast europejskich, przyjęta $\mathrm{z}$ okazji nieformalnego spotkania ministrów w sprawie rozwoju miast i spójności terytorialnej w Lipsku, w dniach 24-25 maja 2007 r. CdR 163/2007 EN - AW(ASZ)/ak.

Klasik A., Kreatywne i atrakcyjne miasta. Koncepcje $i$ mechanizmy restrukturyzacji aglomeracji miejskich [w:] Kreatywna aglomeracja - potencjaty, mechanizmy, aktywności. Podejścia metodologiczne, Klasik A. (red.), Prace Naukowe Akademii Ekonomicznej im. K. Adamieckiego w Katowicach, Wydawnictwo Akademii Ekonomicznej w Katowicach, Katowice 2008.

Klasik A., Od sektora kultury do przemystów kreatywnych [w:] Gwóźdź A. (red.), Od przemystów kultury do kreatywnej gospodarki, Narodowe Centrum Kultury, Warszawa 2010.

Kuźnik F., Modele kreatywnej aglomeracji miejskiej [w:] Kreatywna aglomeracja potencjaty, mechanizmy, aktywności. Podejścia metodologiczne, Klasik A. (red.), Prace Naukowe Akademii Ekonomicznej im. K. Adamieckiego w Katowicach, Wydawnictwo Akademii Ekonomicznej w Katowicach, Katowice 2008. 
Landry Ch., Bianchini F., The creative city, Demos Paper 1995, no. 12.

Latimer-Knowles P.J., Communicative place-making: participatory planning and the enhancement of sense, The 4th International Conference of the International Forum on Urbanism (IFoU) 2009 Amsterdam/Delft The New Urban Question - Urbanism beyond Neo-Liberalism 2009.

Lisowski A., „Przestrzeń” $i$,percepcja” $w$ trans dyscyplinarnych badaniach miast spojrzenie geografa [w:] Percepcja współczesnej przestrzeni miejskiej, Madurowicz M. (red.), Uniwersytet Warszawski, Wydział Geografii i Studiów Regionalnych, Instytut Geografii Społeczno-Ekonomicznej i Gospodarki Przestrzennej, Warszawa 2007.

Lorens P., Definiowanie współczesnej przestrzeni publicznej [w:] Miasto, metropolia, region. Wybrane zagadnienia rewitalizacji miast, Lorens P., Martyniuk-Pęczek J. (red.), Wydawnictwo Urbanista, Gdańsk 2010.

Lorens P., Współczesne tendencje rozwoju struktur miejskich. Znaczenie procesów przekształceń i rewitalizacji [w:] Miasto, metropolia, region. Wybrane zagadnienia rewitalizacji miast, Lorens P., Martyniuk-Pęczek J. (red.), Wydawnictwo Urbanista, Gdańsk 2010.

Lucas R.E., On the Mechanics of Economic Development, Journal of Monetary Economics, 1988, no. 22.

Matur V. K., Human capital-based strategy for regional economic development, Economic Development Quarterly 1999.

New Century City Developments creating extraordinary value, Third Global Workshop. November 9-11, Seoul, Korea 2009. Szerzej także: J. Gehl, Życie między budynkami. Użytkowanie przestrzeni publicznych, Wydawnictwo RAM, Kraków 2009.

Nowakowska A., Przygodzki Z., Sokołowicz M., Region w gospodarce opartej na wiedzy. Kapitat ludzki, innowacje, korporacje transnarodowe, Wydawnictwo Difin, Warszawa 2011.

Nowakowska A., Regionalny wymiar procesów innowacji, Wydawnictwo Uniwersytetu Łódzkiego, Łódź 2011.

Petrikova K., Vanova A., Borsekova K., The role of creative economy in Slovak Republic, Springer-Verlag London 2013, AI \& Soc DOI 10.1007/s00146-013-0508-5.

Przygodzki Z. Kreatywność i zdolności innowacyjne kapitału ludzkiego, w kontekście warunków kształtowania jakości otoczenia lokalnego [w:] Oblicza innowacyjności $w$ regionie, Sokołowicz M. E., Kina E. (red.), Acta Universitatis Lodziensis. Folia Oeconomica 290, Łódź 2013.

Santagata W., Bertacchini E., Creative atmosphere: cultural industries and local development, International Centre for Research on the Economics of Culture, Institutions, and Creativity (EBLA), Working paper 2011, no. 4.

Stangel M., Możliwości technologii informacyjnych i komunikacyjnych (ICT) w procesach rewitalizacji [w:] Miasto, metropolia, region. Wybrane zagadnienia rewitalizacji miast, Lorens P., Martyniuk-Pęczek J., (red.), Wydawnictwo Urbanista, Gdańsk 2009.

Throsby D., Ekonomia i kultura, Narodowe Centrum Kultury 2010.

Törnqvist G., Creativity and the renewal of regional life [w:] Creativity and Context, Buttimer A. (red.), Lund Studies in Geography, B. Human Geography, 1983, no. 50.

Wiśniewska W., Krajobraz miejski: odnowa i kreacja $w$ procesie odnowy, Wydawnictwo Politechniki Łódzkiej, Łódź 2012. 
Załącznik 1. Przykład zrealizowanej karty audytu przestrzeni publicznych

Nazwa: Poludniowa część kampusu Politechniki Łódzkiej

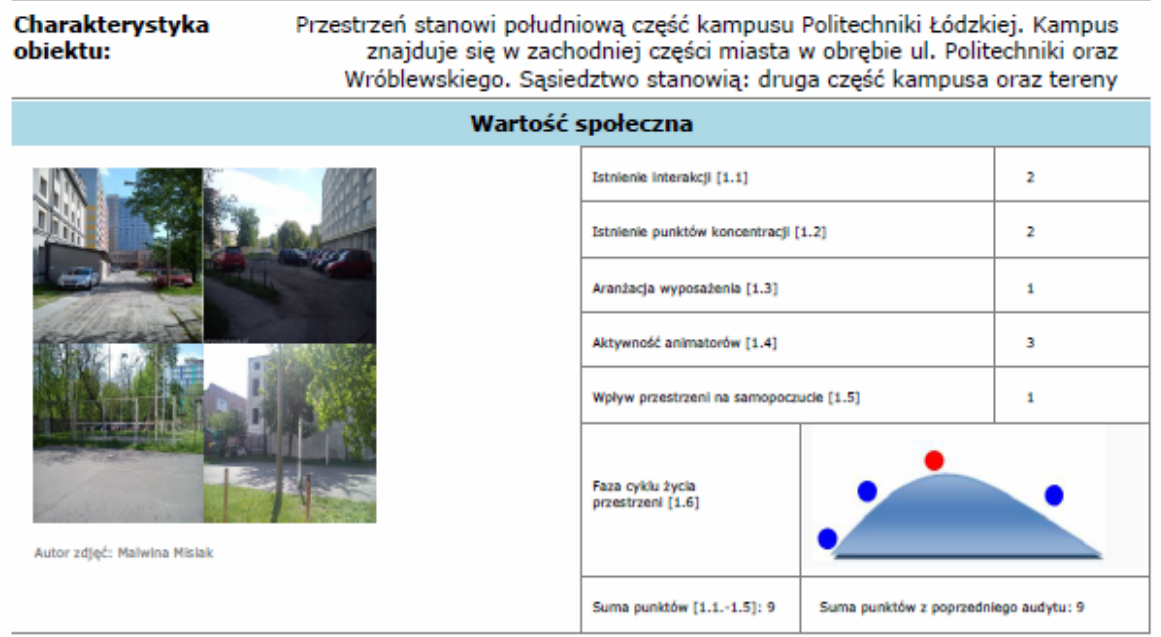

Uwagi audytorów:

W przestrzeni brabuje elementów infrastruktury, ketore ulatwialyby komunikacje pomiedry ulytkownikaml, np. lawek. Wszechobecne samochooy utrudniaja kontakity, odnosi sie

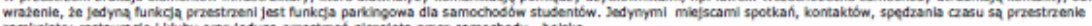
zamknięte: restauracje I kluby oraz jedyna przestrzen niezajęta przez samochody - bolkko.

\section{Zalecenia audytorów:}

Konieczne jest uporzadkowanie przestrzeni poprzez wyznaccenie stref wolnych od samochodów oraz poprawę crystoscl. W dlaszej kolejnobel nalezy odnowic bokkka, postawic

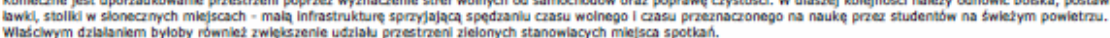

\begin{tabular}{|c|c|c|c|}
\hline \multicolumn{4}{|c|}{ Komfort i wizerunek } \\
\hline I Y $A 7$ & \multicolumn{2}{|l|}{ Notliwati spacerowania $[2.1]$} & 3 \\
\hline & \multicolumn{2}{|c|}{ Istnienie miejsc do siodzenia [2.2] } & 1 \\
\hline & \multicolumn{2}{|l|}{ Bezpiecreistwo [2.3] } & 5 \\
\hline & \multicolumn{2}{|l|}{ Zleionose $[2.4]$} & 2 \\
\hline & \multicolumn{2}{|l|}{ Atrakcyjnoti [2.5] } & 0 \\
\hline & \multicolumn{2}{|l|}{ Crystosc $[2.6]$} & 1 \\
\hline & \multicolumn{2}{|c|}{ Zabezplecrenie I poziom sanitamy [2.7] } & 5 \\
\hline Autor $2 \mathrm{~d} \mid \phi \&$; Maiwina Masiak & Suma punitób $[2.1 \cdot 2.7]: 17$ & Suma & audytu: 17 \\
\hline
\end{tabular}

Uwagi audytorów:

Mimo u w prastrzeni jest dulo miejsca do spracerowanla, nie jest to przyjemne ze wzgledu na samochody. Brakuje miejec siedzacych. Przestrzen jest bezplecrna nie znajduja

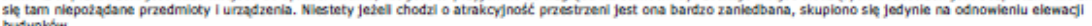
buđyniów.

Zalecenia audytorów:

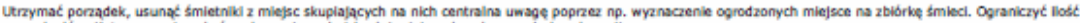
samochodow. Kategorycznie zakac parkowanis na boikiach I miejscach wskazanych do rekereacji. 
238 Audyt przestrzeni publicznych, jako narzędzie monitorowania...

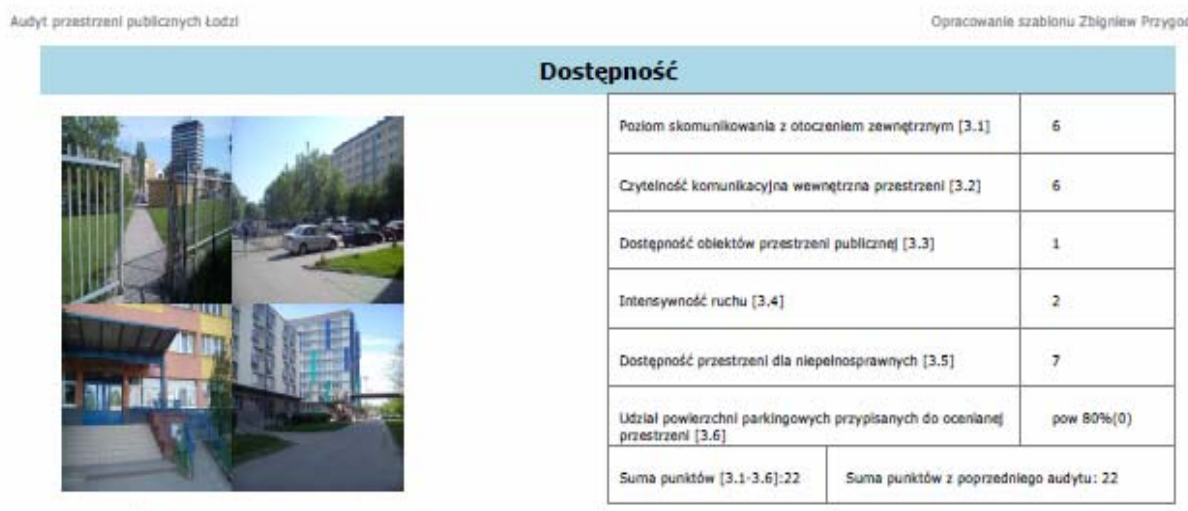

Autor adję: Malwina Misiaz

Uwagi audytorów:

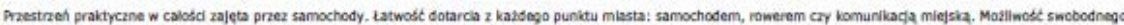
ponuszania sig ascb niepolnosprawnych ze maglegy na plattarmy do budynkbu I brak schodow w przestrzenL.

\section{Zalecenia audytorów:}

Najwiekszym probiomem jest zbyt ouza lcaba samochoobw, przy jel ogranicaeniu oraz uporzadkowaniu prastrzenl: wprowadzeniu lawek, murków, stolindw, zamkniegciu

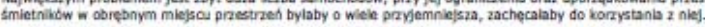

\begin{tabular}{|c|c|c|c|}
\hline \multicolumn{4}{|c|}{ Funkcje i działania } \\
\hline & \multicolumn{2}{|c|}{ Cry widać, te przestreef jest zarzadrans? [4,1] } & 3 \\
\hline & \multicolumn{2}{|c|}{$\begin{array}{l}\text { Utytecanobic - w stosuniku do adresowanef grupy } \\
\text { utythownikdow }[4.2]\end{array}$} & 2 \\
\hline & \multicolumn{2}{|c|}{ Zrobtnicowanie ulythownlików ze wrgiędu na miek [4.3] } & 1 \\
\hline & \multicolumn{2}{|c|}{ Nonkonformirm rachowah ulythownikdw [4.4] } & 0 \\
\hline & 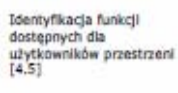 & \multicolumn{2}{|c|}{ UAydownily: praktycanie sami studend } \\
\hline Autor 2 dject: Maiwina Nesist & Suma punitbo $[3.1 \cdot 3.6]=6$ & \multicolumn{2}{|c|}{ Suma punitedw 2 poprzedniego audytu: } \\
\hline
\end{tabular}

\section{Uwagi audytorów:}

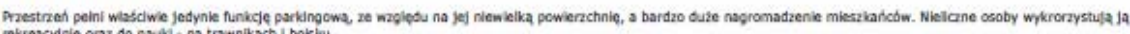

\section{Zalecenia audytorów:}

Odnowienie bolska - powierzchni oraz postawienie nowych koszy do gry, zachęcaloby do skorzystania z przestrzent. Probiemem jest dujla llobic samochodów, potrzebny jest w

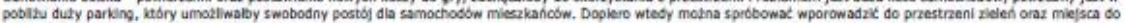
spotkan: lawkl, murki cry stoliki, stoly do ping-ponga.

\begin{tabular}{|c|c|c|c|}
\hline Autory: & $\begin{array}{l}\text { 1. Olejnicanik Patryk } \\
\text { 2. Olanyhisia Karodina } \\
\text { 3. Mikiak Maiwing }\end{array}$ & $\begin{array}{l}\text { Duta | Codrina } \\
\text { obserwac|ll: }\end{array}$ & $\begin{array}{l}1.14 .05 .2013 \text { godz. } 14.40-15.10 \\
2.9 .05 .2013 \% \operatorname{godz} .11 .45 \\
3.15 .05 .2013, \operatorname{godz} 18.00-19.00\end{array}$ \\
\hline
\end{tabular}

